ROCZNIKI NAUK PRAWNYCH

Tom XXXI, numer 3 - 2021, s. 77-91

DOI: http://doi.org/10.18290/rnp21313.5

\author{
ADRIANNA NIEGIEREWICZ-BIERNACKA \\ Uniwersytet w Białymstoku \\ adrianna_niegierewicz@wp.pl \\ ORCID: https://orcid.org/0000-0002-1639-3975
}

\title{
ODPOWIEDZIALNOŚĆ KARNA OSOBY SPORZĄDZAJĄCEJ FAŁSZYWĄ OPINIĘ PRYWATNĄ DLA CELÓW PROCESU KARNEGO*
}

\author{
CRIMINAL LIABILITY OF A PERSON PREPARING A FALSE PRIVATE OPINION \\ FOR THE PURPOSES OF A CRIMINAL TRIAL
}

\begin{abstract}
With the amendment to the Code of Criminal Procedure introduced by the Act of 27 September 2013 amending the Act - Code of Criminal Procedure and some other acts (Journal of Laws of 2013, item 1247, as amended), the legislator changed Art. $393 \S 3$ of the Code of Criminal Procedure, introducing the possibility of using a private opinion in the course of criminal proceedings. Such a possibility may result in the appearance of unreliable and false private opinions in the evidence. In this context, the aim of the article is to answer the question: can the author of a false private opinion used in criminal proceedings be criminally liable for drawing up such an opinion under Art. 233 of the Penal Code, and if so, what is this liability conditioned by? The article presents the results of a nationwide survey conducted among judges of criminal departments, and an analysis of the premises of the offence Art. $233 \S 1$ or 4, 4a of the Criminal Code. The article contains de lege ferenda conclusions.
\end{abstract}

Keywords: criminal proceedings; false private opinion; criminal liability

\section{WPROWADZENIE}

Nowelizacją kodeksu postępowania karnego dokonanej ustawą z dnia 27 września 2013 r. o zmianie ustawy - Kodeks postępowania karnego oraz

\footnotetext{
* Niniejszy artykuł powstał w ramach projektu badawczego pt. „Wpływ ekspertyzy prywatnej na wykrycie prawdy materialnej w polskim procesie karnym", finansowanego przez Narodowe Centrum Nauki (projekt badawczy nr 2019/33/N/HS5/01626, umowa nr UMO-2019/33/N/HS5/ 01626), kierownik projektu: Adrianna Niegierewicz-Biernacka.
} 
niektórych innych ustaw ${ }^{1}$ ustawodawca zmienił przepis art. $393 \S 3$ Kodeksu postępowania karnego ${ }^{2}$, rozszerzając krąg dokumentów podlegających odczytaniu na rozprawie. Zgodnie z obecnym brzmieniem przepisu, mogą to być wszelkie dokumenty prywatne, powstałe poza postępowaniem karnym, w szczególności oświadczenia, publikacje, listy oraz notatki. Przepis ten wprowadza tym samym możliwość procesowego wykorzystania w toku postępowania karnego tzw. opinii (ekspertyzy) prywatnej, która, jeśli zostanie dopuszczona przez organ procesowy jako dowód, może mieć istotny wpływ na przebieg postępowania dowodowego, $\mathrm{w}$ tym także na podejmowane przez organ procesowy decyzje. To może spowodować pojawienie się w materiale dowodowym opinii prywatnych nierzetelnych, w tym również nieprawdziwych, które mimo iż nie mogą zastąpić opinii biegłego powołanego przez organ procesowy, to jednak stanowią dowód podlegający ocenie zgodnie z przepisem art. 7 k.p.k.

Celem artykułu jest zatem zbadanie możliwości ponoszenia odpowiedzialności karnej przez autora opinii prywatnej (tzw. biegłego/eksperta prywatnego) za sporządzenie fałszywej opinii prywatnej na podstawie przepisu art. 233 k.k. ${ }^{3}$ Ekspertyza prywatna jest bowiem szczególnie narażona na różnego rodzaju mankamenty. Mianowicie może być sporządzana na podstawie części materiału dowodowego bądź ekspert prywatny może kierować się chęcią zadowolenia osoby zlecającej mu przygotowanie ekspertyzy. To zaś może powodować, że taka ekspertyza nie uwzględnia wszystkich istotnych dla rozstrzygnięcia konkretnej kwestii okoliczności, oparta jest na wybiórczych dowodach ${ }^{4}$, może też sprawiać wrażenie niejasnej w sytuacji, gdy wnioski w niej zawarte nie budzą zastrzeżeń, jednakże sposób ich ustalenia nie jest możliwy do zrozumienia. Na jej nierzetelność, a w tym fałszywość może wpływać wiele czynników, począwszy od dostępu do materiału dowodowego sprawy, dalej - od kwalifikacji podmiotu sporządzającego ekspertyzę, następnie od relacji między podmiotem zlecającym opinię a osobą ją sporządzającą, czy też czasu jej wykonania.

\footnotetext{
${ }^{1}$ Ustawa z dnia 27 września 2013 r. o zmianie ustawy - Kodeks postępowania karnego oraz niektórych innych ustaw, Dz.U. z 2013 r., poz. 1247 ze zm.

${ }^{2}$ Ustawa z dnia 6 czerwca 1997 r. - Kodeks postępowania karnego, Dz.U. z 1997 r., Nr 89, poz. 555 ze zm. [dalej k.p.k.].

${ }^{3}$ Ustawa z dnia 19 kwietnia 1969 r. - Kodeks karny, Dz.U. z 1969 r., Nr 13, poz. 94 ze zm. [dalej k.k.].

${ }^{4}$ Wyrok SN z 9.05.1988 r., II KR 96/88, OSNKW 1988/9-10, poz. 27.
} 
W literaturze przedmiotu wskazuje się, że opinia fałszywa to taka, w której potwierdzono nieprawdę lub zatajono prawdę, gdy zawarte w niej wnioski będą wyraźnie sprzeczne z aktualnym stanem wiedzy w dziedzinie, której opinia dotyczy, lub wnioski będą wyraźnie sprzeczne z rzeczywistym stanem faktycznym i oparte na błędnych metodach badawczych ${ }^{6}$. Natomiast opinia nierzetelna byłaby wówczas, gdyby zawarte $\mathrm{w}$ niej informacje nie były wprost nieprawdziwe, ale niepełne lub sugerujące niezgodny z rzeczywistością stan rzeczy, pomijałaby niektóre informacje lub sugerowała treści nieprawdziwe, choć nie zawierałaby wprost informacji nieprawdziwych ${ }^{7}$.

Realizacja wyżej opisanego celu możliwa będzie dzięki przeprowadzeniu analizy problemu badawczego, który zawiera się w pytaniu: czy autor fałszywej opinii prywatnej wykorzystanej w postępowaniu karnym może ponieść za jej sporządzenie odpowiedzialność karną na podstawie przepisu art. 233 k.k., a jeśli tak, to czym ta odpowiedzialność jest uwarunkowana? Mając na uwadze tak postawione pytanie, hipoteza badawcza zakłada, że na gruncie obowiązującego przepisu art. 233 k.k. autor prywatnej opinii przygotowanej na zlecenie nieinstytucjonalnego uczestnika postępowania karnego nie może ponieść odpowiedzialności karnej za sporządzenie dla celów postępowania karnego fałszywej opinii prywatnej. Hipoteza ta będzie podlegała weryfikacji przy wykorzystaniu metody badawczej analizy dogmatyczno-prawnej i teoretyczno-prawnej. Dużą rolę odegrała również metoda empiryczna badań sondażowych techniką ankiety. Podkreślenia wymaga to, iż motywem, który skłonił do zajęcia się tą problematyką, były wyniki ogólnopolskich badań ankietowych przeprowadzonych wśród sędziów wydziałów karnych, które nie przedstawiały jednolitego stanowiska w zakresie ponoszenia przez eksperta prywatnego odpowiedzialności karnej za sporządzenie fałszywej ekspertyzy prywatnej (o których w dalszej części artykułu).

${ }^{5}$ M. BUdyn-KULIK, Kilka uwag o przestęstwie z art. 233 k.k. (sktadanie fatszywych zeznań) po nowelizacji z 11 marca 2016 r., „Annales Universitatis Maria Curie-Skłodowska”, sectio G. Ius, 63 (2016) 1, s. 29.

${ }^{6}$ B. KUnICKA-MichalSKA, Komentarz do art. 233 kk, [w:] Kodeks karny. Komentarz, red. A. Wąsek, R. Zawłocki, t. II, Warszawa: C.H. Beck 2006, s. 149; T. WIDŁA, Odpowiedzialność karna za wydanie fatszywej opinii, „Palestra” 63 (2018), nr 10, s. 13-18.

${ }^{7}$ M. BUDYN-KULIK, Kilka uwag o przestepstwie, s. 33 i podana tam literatura. 


\section{POJĘCIE OPINII PRYWATNEJ}

Zasadnicze rozważania będące przedmiotem niniejszego artykułu poprzedzić warto wyjaśnieniem pojęcia „opinia prywatna”. W literaturze przedmiotu poszczególni przedstawiciele doktryny prezentują różne definicje, które co prawda są w większości zbieżne, choć niekiedy akcentują inne cechy i wartości. Według J. Zagrodnika opinia prywatna „sporządzona jest przez rzeczoznawcę (specjalistę lub biegłego) na zlecenie uczestnika procesu karnego, niebędącego organem prowadzącym postępowanie karne, na danym jego etapie" ${ }^{8}$. W swojej definicji zwraca uwagę na element podmiotu sporządzającego opinię (rzeczoznawca, specjalista lub biegły), która może być wykonana i wprowadzona do procesu na określonym jego etapie (tj. postępowanie przygotowawcze i sądowe), jak również precyzuje podmiot zlecający jej dokonanie poprzez wskazanie, że jest to uczestnik procesu, ale niebędący organem prowadzącym postępowanie karne.

Z kolei według L.K. Paprzyckiego opinia prywatna to „dokument, którego autor, na zlecenie uczestnika postępowania, dokonując ustalenia okoliczności istotnych w sprawie, wykorzystał posiadane przez siebie wiadomości specjalne w rozumieniu art. $193 \S 1$ k.p.k., a zatem dokument w rozumieniu art. 115 $\S 14$ k.k., oznaczający każdy nośnik informacji, który ze względu na zawartą w nim treść stanowi dowód okoliczności mającej istotne znaczenie w sprawie"9.

J. Skorupka zwraca uwagę na źródło pochodzenia (wytworzenia) opinii, wskazując, że nie pochodzi ona od biegłego powołanego przez organ procesowy (tzw. biegłego urzędowego lub biegłego instytucjonalnego), a od eksperta (specjalisty) posiadającego wiadomości specjalne w danej dziedzinie, pozwalające na stwierdzenie okoliczności mających istotne znaczenie dla rozstrzygnięcia sprawy ${ }^{10}$. Nie nazywa zatem podmiotu sporządzającego opinię biegłym (prywatnym), lecz ekspertem czy specjalistą.

R. Ponikowski i J. Zagrodnik dodają dodatkowo do definicji cel sporządzenia opinii, $\mathrm{tj}$. dowodowe wykorzystanie $\mathrm{w}$ toczącym się postępowaniu karnym

${ }^{8}$ J. ZAGrodnik, Opinia prywatna w procesie karnym, [w:] Ogólnopolska Konferencja Naukowa 10-11 maj 2005 r. Dowody w procesie karnym, nowe rozwiazania i niewykorzystane możliwości, oprac. Koło Naukowe Sympatyków Prawa; opiekun nauk. K. Marszał, Katowice: Uniwersytet Śląski. Wydział Prawa i Administracji 2005, s. 67-68.

${ }^{9}$ L.K. PAPRZYCKI, Wykorzystanie opinii prywatnej w postępowaniu karnym, [w:] Prawo wobec problemów społecznych. Ksiega jubileuszowa profesor Eleonory Zielińskiej, red. B. NamysłowskaGabrysiak, K. Syroka-Marczewska, A.Walczak-Żochowska, Warszawa: C.H. Beck 2016, s. 279.

$10 \mathrm{~J}$. SKORUPKA, Tzw. opinia prywatna wedtug noweli Kodeksu postępowania karnego z 27.09.2013 r., [w:] Rola biegłego w postępowaniach sądowych, red. Ł. Błaszczak, K. Markiewicz, Wrocław: Presscom 2016, s. 232. 
i kategoryzują podmioty, które mogą taką opinię wykonać: osoby mające wiedzę specjalną, w tym niekiedy przez biegłych z listy sądowej, instytutów i instytucji naukowych ${ }^{11}$. B. Bieńkowska nazywa „opinię prywatną” wynikiem pracy rzeczoznawców, którzy swoje ekspertyzy wykonują na zlecenie stron procesowych ${ }^{12}$, podkreślając tym samym, że jest to efekt pracy rzeczoznawcy. A. Bojańczyk dodatkowo zwraca uwagę na aspekt sporządzenia ekspertyzy zleconej przez stronę wedle parametrów wskazanych przez nią w zleceniu ${ }^{13}$.

Mając na uwadze powyższe definicje, wyodrębnić można następujące cechy ekspertyzy prywatnej ${ }^{14}$ : wykonanie ekspertyzy na zlecenie uczestnika procesu karnego niebędącego organem prowadzącym postępowanie karne, w którym to zleceniu mogą zostać wskazane cele i parametry, którymi kierować się ma autor sporządzający ekspertyzę; opinia jest nośnikiem informacji, zaś informacją jest okoliczność istotna w sprawie; celem autora opinii jest ustalenie okoliczności istotnej w sprawie, a powstała opinia pozostaje efektem jego pracy; autor opinii posiada informacje specjalne w rozumieniu art. $193 \S 1$ k.p.k. z danej dziedziny (wybranej przez zlecającego uczestnika), kieruje się celem jej sporządzenia, tj. dowodowym wykorzystaniem w toczącym się postępowaniu karnym, aby uzasadnić twierdzenia strony co do faktów; przed wszczęciem postępowania karnego, jak i w jego trakcie (ale nie w ramach czynności prowadzonego postępowania) może powstać dokument prywatny zawierający wiadomości specjalne, w związku z toczącym się postępowaniem karnym, na koszt uczestnika zlecającego.

\section{ODPOWIEDZIALNOŚĆ KARNA EKSPERTA PRYWATNEGO W ŚWIETLE BADAŃ ANKIETOWYCH}

Jak wspomniano we wstępie artykułu, motywem, który skłonił do pogłębienia problematyki ponoszenia przez eksperta prywatnego odpowiedzialności karnej za sporządzenie fałszywej ekspertyzy prywatnej, były wyniki

\footnotetext{
${ }^{11}$ R. PONIKOWSKI, J. ZagrodniK, Komentarz do art. 393 kpk, [w:] Komentarz postepowania karnego, red. J. Skorupka, wyd. 28, Legalis.

${ }^{12}$ B. BIEŃKowska, Opinia prywatna biegłego $w$ świetle nowelizacji kodeksu postępowania karnego ustawa z dnia 27 września 2013 r., [w:] Wokót gwarancji wspótczesnego procesu karnego. Księga jubileuszowa Profesora Piotra Kruszyńskiego, red. M. Rogacka-Rzewnicka, H. Gajewska-Kraczkowska, B.T. Bieńkowska, Warszawa: Wolters Kluwer Polska 2015, s. 25.

${ }^{13}$ A. BOJAŃCZYK, Czy znowelizowane przepisy procedury karnej pozwalaja obrońcy na korzystanie z opinii prywatnych?, „Palestra” 60 (2015), nr 3-4, s. 200.

${ }^{14}$ M. KUSAK, Opinia prywatna, [w:] System prawa karnego procesowego, t. VIII: Dowody, cz. 4, red. J. Skorupka, Warszawa: Wolters Kluwer 2019, s. 5377-5393.
} 
ogólnopolskich badań empirycznych metodą sondażu diagnostycznego techniką ankiety (dalej: badania ankietowe), przeprowadzonych wśród sędziów wydziałów karnych sądów powszechnych w ramach wymienionego grantu badawczego ${ }^{15}$. Celem badań ankietowych było poznanie opinii sędziów o możliwości wykorzystania opinii (ekspertyzy) prywatnej i jej roli w postępowaniu karnym. Znaczącą większość pytań skierowanych do sędziów stanowiły pytania zamknięte lub półotwarte $\mathrm{z}$ uwagi na chęć uzyskania wyczerpującego katalogu odpowiedzi i umożliwienia wyrażenia swojej opinii przez respondenta (dodana została odpowiedź „inne”). Tak też zostało sformułowane pytanie odnoszące się do kwestii ponoszenia odpowiedzialności karnej przez eksperta prywatnego. Respondentom zadano pytanie: „Czy Pana/Pani zdaniem podmiot sporządzający fałszywą ekspertyzę prywatną może ponosić odpowiedzialność karną?". W sytuacji, w której respondent uważałby, że właściwa byłaby kwalifikacja prawna w zbiegu przestępstw lub też zasadne byłoby wskazanie kilku odpowiedzi lub też tej (kwalifikacji prawnej) niewymienionej $\mathrm{w}$ zaproponowanych odpowiedziach, respondent mógł wyrazić swoją opinię udzielając własnej odpowiedzi. Wyniki przeprowadzonego sondażu prezentuje wykres 1 .

Wykres 1. Odpowiedzialność karna autora fałszywej ekspertyzy prywatnej wedle opinii sędziów w ujęciu procentowym

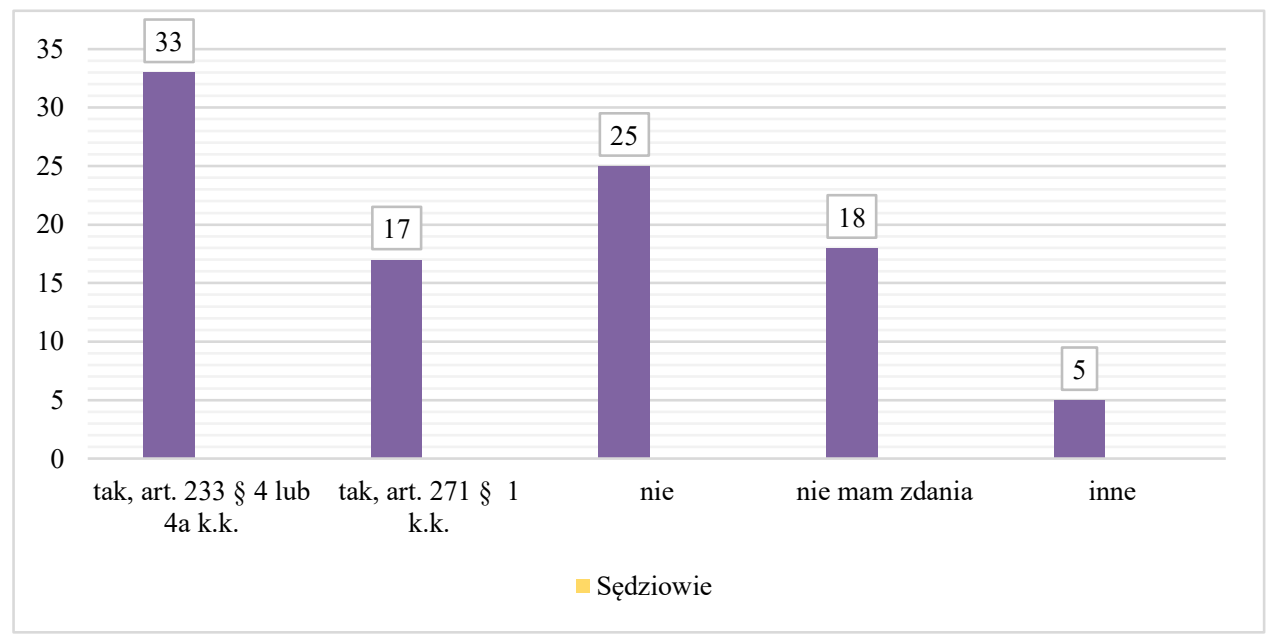

Źródło: Opracowanie własne

${ }^{15}$ Liczba respondentów (sędziów) wynosiła 299 osób, z czego 16 osób to sędziowie sądów apelacyjnych, 38 - to sędziowie sądów okręgowych, zaś 245 - to sędziowie sądów rejonowych. Wykonawca badań: Adrianna Niegierewicz-Biernacka. 
Z wykresu wynika, że zdaniem większości respondentów ekspert prywatny powinien ponosić odpowiedzialność karną na podstawie przepisu art. 233 § 4 lub 4a k.k. Takiej odpowiedzi udzieliło 33\% sędziów. Natomiast 25\% sędziów wskazało, że ekspert prywatny nie powinien ponosić odpowiedzialności karnej. 18\% respondentów wybrało odpowiedź: „nie mam zdania”, zaś 17\% wskazało, że odpowiedzialność ta powinna być ponoszona na gruncie przepisu art. $271 \S 1$ k.k. Umożliwienie respondentom wypowiedzenia się w ramach pytania półotwartego zaowocowało interesującymi i wartymi rozważań odpowiedziami. Sędziowie wskazali na takie kwalifikacje prawne, jak: art. 235 k.k. (3 odpowiedzi), art. $239 \S 1$ k.k. (3 odpowiedzi), art. $18 \S 3$ k.k. w zw. z art. $286 \S 1$ k.k. (jeśli sprawa ma aspekt majątkowy, jedna odpowiedź), art. $212 \S 1$ k.k., art. $233 \S 4$ i 4a k.k. w sytuacji, gdy ekspert prywatny zostanie powołany w sprawie jako biegły i pouczony o odpowiedzialności karnej (3 odpowiedzi). Pojawiła się także jedna odpowiedź, że biegły z listy sądu okręgowego nie powinien sporządzać opinii prywatnych pod groźbą wykreślenia $\mathrm{z}$ listy.

Przedstawione dane uzasadniają pogląd, iż opisywana problematyka jest istotna dla praktyki wymiaru sprawiedliwości. Nadal przysparza wiele problemów natury praktycznej. Odpowiedzi sędziów były zróżnicowane, przez co uzyskane wyniki nie dają możliwości poczynienia na ich podstawie konstruktywnych wniosków w zakresie ponoszenia odpowiedzialności karnej przez eksperta prywatnego. Stąd konieczna stała się pogłębiona analiza znamion strony podmiotowej i przedmiotowej czynu stypizowanego w art. $233 \S 4$ k.k. i art. $271 \S 1$ k.k. Wynik ten pozwala także na wysnucie konkluzji, iż brak opracowania w doktrynie procesu karnego problematyki statusu ekspertyzy prywatnej oraz eksperta prywatnego nie pozwala na pewne i konstruktywne wyrażenie opinii przez sędziów w przedstawionym zagadnieniu badawczym.

$\mathrm{Z}$ racji tego, że badani respondenci najczęściej wskazywali kwalifikację prawną z art. $233 \S 4$ i 4a k.k., dalsze rozważania będą dotyczyły możliwości ponoszenia odpowiedzialności karnej przez tzw. biegłego prywatnego na podstawie art. 233 k.k. ze szczególnym uwzględnieniem $\S 4$ i 4 tego przepisu.

\section{ODPOWIEDZIALNOŚĆ EKSPERTA PRYWATNEGO SPORZĄDZAJĄCEGO EKSPERTYZĘ PRYWATNĄ DLA CELÓW POSTĘPOWANIA KARNEGO NA PODSTAWIE PRZEPISU ART. 233 K.K.}

Przepisy kodeksu karnego penalizują zachowanie biegłego w postaci przedstawienia fałszywej opinii, ekspertyzy lub tłumaczenia mającego służyć za 
dowód w postępowaniu sądowym lub w innym postępowaniu prowadzonym na podstawie ustawy w przepisie art. $233 \S 4$ i 4 a k.k. Warto zatem zastanowić się nad możliwością ponoszenia odpowiedzialności karnej przez autora ekspertyzy prywatnej na podstawie tego przepisu, tym bardziej $\mathrm{z}$ uwagi na to, że w wyniku nowelizacji kodeksu karnego z 11 marca 2016 r. ${ }^{16}$ do treści przepisu dodano nowe znamię (wymieniono dokument w postaci ekspertyzy) i podwyższono sankcję.

W pierwszej kolejności przeanalizować należy znamię podmiotu. Podmiotem przestępstwa $\mathrm{z}$ art. 233 k.k. może być odpowiednio: tylko świadek składający zeznanie mające służyć za dowód w postępowaniu sądowym lub $\mathrm{w}$ innym postępowaniu prowadzonym na podstawie ustawy (w zakresie czynu $\mathrm{z}$ art. $233 \S 1$ i 1a k.k.), biegły, rzeczoznawca lub thumacz (w zakresie czynu z art. $233 \S 4$ i 4a k.k.) albo osoba składająca oświadczenie (w zakresie czynu z art. $233 \S 6$ k.k.). Warto przy tym zauważyć, że ustawodawca wprowadzając nowelą z dnia 27 września 2013 r. ${ }^{17}$ od 1 lipca 2015 r. możliwość wykorzystania w procesie karnym ekspertyzy prywatnej, nie skorelował tej zmiany z brzmieniem opisywanego przepisu k.k. Przepis art. 233 k.k. nie wymienia bowiem w swojej treści wyraźnie znamienia podmiotu, jakim jest ekspert prywatny. Nowelizacją dokonaną ustawą z dnia 11 marca 2016 r. $^{18}$ dodano w art. $233 \S 4$ k.k. (i w kolejnych jednostkach redakcyjnych) obok terminu „opinia” i „tłumaczenie”, także termin „ekspertyzy”, sugerujący możliwość ponoszenia na gruncie tego przepisu odpowiedzialności karnej również przez autora ekspertyzy prywatnej (o czym w dalszej części artykułu).

Odnosząc się do wymienionych przez ustawodawcę w art. $233 \S 4$ k.k. podmiotów, wyjaśnienia wymaga to, co mieści się w określeniu „biegły” oraz „rzeczoznawca” i czy któreś z tych pojęć obejmuje również osobę sporządzającą prywatną opinię. Pierwszym podmiotem wymienionym przez ustawodawcę w art. $233 \S 4$ k.k. jest biegły. Chodzi jednak o biegłego powołanego przez organ procesowy w trybie przepisów Kodeksu postępowania karnego (art. 193 § 1 k.p.k. i nast.) w sytuacji, gdy stwierdzenie okoliczności mających istotne znaczenie dla rozstrzygnięcia sprawy wymaga wiadomości specjalnych. W znaczeniu procesowym biegły jest osobą, która zostaje powołana mocą postanowienia przez organ procesowy do stwierdzenia okoliczności

\footnotetext{
${ }^{16}$ Ustawa z dnia 11 marca 2016 r. o zmianie ustawy - Kodeks postępowania karnego oraz niektórych innych ustaw, Dz.U. z 2016 r., poz. 437.

${ }^{17}$ Ustawa z dnia 27 września 2013 r. o zmianie ustawy - Kodeks postępowania karnego oraz niektórych innych ustaw, Dz.U. z 2013 r., poz. 1247 ze zm.

${ }^{18}$ Ustawa $\mathrm{z}$ dnia 11 marca 2016 r. o zmianie ustawy - Kodeks postępowania karnego oraz niektórych innych ustaw, Dz.U. z 2016 r., poz. 437.
} 
mających istotne znaczenie dla rozstrzygnięcia, a wymagających wiadomości specjalnych ${ }^{19}$. W doktrynie wskazuje się, że tzw. opinia prywatna nie ma statusu opinii biegłego, a ekspert ją sporządzający - statusu biegłego ${ }^{20}$. Pojęcie „biegłego" nie obejmuje zatem tzw. biegłego prywatnego nawet wówczas, gdy autor opinii prywatnej znajduje się na liście biegłych sądowych sądu okręgowego. Na marginesie zaznaczyć warto, iż określenia „biegły prywatny” i „opinia prywatna” są nazwami wywołującymi skojarzenia z procesowo powołanym biegłym procesowym i sporządzoną przez niego opinią, stąd też są określeniami niefortunnymi.

Pewne trudności może sprawiać interpretacja terminu „rzeczoznawca”. Pojęcie to jest bardzo szerokie i występuje w wielu ustawach - jak przykładowo rzeczoznawca majątkowy, rzeczoznawca budowlany, rzeczoznawca z zakresu prac geodezyjnych i kartograficznych, rzeczoznawca samochodowy. Mając na uwadze przedmiot ochrony i wskazany katalog podmiotów, jakie ponoszą odpowiedzialność na podstawie tego przepisu, poczynić warto uwagę natury ogólnej, zarysowaną już wcześniej, a sprowadzającą się do tego, że zachowanie penalizowane przez przepis art. $233 \S 4$ i 4a k.k. dotyczy nie tylko postępowania karnego, ale i innych postępowań prowadzonych na podstawie ustawy. Chodzi zatem nie tylko o biegłego i opinię w rozumieniu art. 193 k.p.k. (a więc powołanego przez organ procesowy), a także rzeczoznawcę i wykonywane przez niego ekspertyzy w innych postępowaniach aniżeli postępowanie karne, np. postępowaniach administracyjnych. Dodać należy, że jeśli sąd (bądź organ postępowania przygotowawczego) powoła rzeczoznawcę, to $\mathrm{w}$ charakterze biegłego (a nie rzeczoznawcy) i wówczas sporządzi on opinię (a nie ekspertyzę).

W literaturze występują inne interpretacje pojęcia „rzeczoznawca”, tj. jako podmiotu sporządzającego opinię-ekspertyzę pozaprocesową w tym sensie, że powstaje ona nie na zlecenie instytucjonalnego uczestnika procesu, a na zlecenie strony czy jej obrońcy bądź pełnomocnika, byleby tylko miała stanowić dowód w postępowaniu sądowym bądź innym prowadzonym na podstawie ustawy ${ }^{21}$.

\footnotetext{
${ }^{19}$ K. DudKa, H. PaluszKiewicz, Postępowanie karne, Warszawa: Wolters Kluwer 2018, s. 153.

${ }^{20}$ T. WidŁA, Jeszcze raz o ekspertyzach pozasadowych, „Prokuratura i Prawo” 2015, nr 7-8, s. 36-43; K. EICHSTAEDT, Znaczenie opinii prywatnej w postepowaniu karnym, „Prokuratura i Prawo" 2015, nr 4, s. 90-98; R. KMIECIK, Kontrowersyjne unormowania w znowelizowanym kodeksie postępowania karnego, „Prokuratura i Prawo” 2015, nr 1-2, s. 10-24.

${ }_{21}$ M. NowAK, Wątpliwości zwiazane z odpowiedzialnościa prawna biegłego sąowego w świetle znowelizowanego art. 233 § $4 a$ kk, ,Zeszyty Prawnicze” 17 (2017), nr 2, s. 78-79.
} 
W literaturze można jednak odnaleźć poglądy polemizujące $\mathrm{z}$ takim stanowiskiem, wskazujące, że sposób, w jaki dokonano zlecenia sporządzenia opinii (procesowy bądź pozaprocesowy), nie powinien mieć decydującego znaczenia dla określenia zbioru podmiotów mogących potencjalnie ponosić odpowiedzialność za sfałszowanie opinii w tym sensie, że z owej grupy miałby zostać wyeliminowany autor opinii/ekspertyzy pozaprocesowej ${ }^{22}$. Autor tego zapatrywania argumentuje je tym, że rodzajowym przedmiotem ochrony jest prawidłowe funkcjonowanie wymiaru sprawiedliwości, który został skonkretyzowany w taki sposób, że bezpośredni przedmiot ochrony stanowią prawidłowe ustalenia faktyczne i wydane na tej podstawie orzeczenie opierające się na prawdziwych, a nie fałszywych dowodach ${ }^{23}$. W piśmiennictwie wskazuje się, że nie podlega tej odpowiedzialności biegły lub rzeczoznawca, jeżeli opinia lub ekspertyza została sporządzona dla innych celów, np. jako opinia, ekspertyza prywatna, gdyż nie godzi ona w dobro prawnie chronione, jakim jest prawidłowe funkcjonowanie wymiaru sprawiedliwości ${ }^{24}$.

Ze znamieniem podmiotu ściśle związany jest przedmiot czynności wykonawczej przestępstwa stypizowanego w art. $233 \S 4$ i 4a k.k. Jest nim opinia, tłumaczenie lub ekspertyza, mająca służyć za dowód w postępowaniu sądowym lub w innym postępowaniu prowadzonym na podstawie ustawy. Wprowadzony do znamion tego przepisu nowelą z dnia 11 marca 2016 r. termin „ekspertyza” oraz jego słownikowe znaczenie wskazuje na fachowy podmiot, który ją sporządził. Również przez to zastanawiać się można nad tym, czy intencją ustawodawcy nie było rozszerzenie karalności zachowań w postaci sporządzenia dla strony zlecającej fałszywej ekspertyzy przez eksperta, nawet jeśli chodzi o prywatną ekspertyzę. Jednak należy odrzucić tę koncepcję z uwagi na to, że w rozdziale 22 Kodeksu postępowania karnego pojęcie „ekspertyza" używane jest jako synonim opinii biegłego bądź element jej wydania (art. 194 k.p.k. czy art. $198 \S 3$ k.p.k.) ${ }^{25}$. Zaznaczyć jednak warto, że wypowiedź przedstawicieli projektodawcy w trakcie prac legislacyjnych nad nowelizacją z dnia 11 marca 2016 r. $^{26}$ (w zakresie kryminalizacji nieumyślnych zachowań polegających na przedstawianiu fałszywych opinii)

\footnotetext{
22 Tamże, s. 79.

${ }^{23}$ Uchwała S.N. (7) z 22.02.2003 r., I KZP 39/02, OSNKW 1-2/2003, poz. 1, s. 3.

${ }^{24}$ M. NAwrocki, Komentarz do art. 233 kk, [w:] Kodeks karny. Komentarz, red. Flaga-Gieruszyńska, Warszawa: C.H. Beck 2020, wyd. 2, Legalis.

${ }^{25}$ A. Herzog, Komentarz do art. 233 kk, [w:] Kodeks karny. Komentarz, red. R. Stefański, Warszawa: Wolters Kluwer 2021, wyd. 26, Legalis.

${ }^{26}$ Ustawa z dnia 11 marca 2016 r. o zmianie ustawy - Kodeks postępowania karnego oraz niektórych innych ustaw, Dz.U. z 2016 r., poz. 437.
} 
była potrzebą przeciwdziałania praktyce przedstawiania „opinii nierzetelnych”, w tym przez „prywatnych biegłych”27. Wypowiedź tę, odnoszącą się do potrzeby kryminalizacji zachowań ekspertów prywatnych, z pewnością uznać należy za ówczesny postulat projektodawcy, a ewentualną odpowiedzialność karną odnieść do znamion czynu z art. 233 k.k.

Zasadniczym problemem, jaki pojawia się przy próbie odpowiedzi na pytanie, czy ekspert prywatny może być podmiotem czynu z art. $233 \S 4$ k.k., jest to, że pomimo wprowadzenia możliwości wykorzystania w procesie karnym opinii prywatnej, w przepisach kodeksu postępowania karnego czy innych ustawach (np. ustawie o biegłych) status eksperta prywatnego i opinii (ekspertyzy) prywatnej nie został uregulowany. W literaturze zaś odnaleźć można różne stanowiska interpretacyjne, niektóre $\mathrm{z}$ nich prezentują rozszerzające koncepcje, gdzie z uwagi na przedmiot ochrony przestępstwa, posiadanie wiedzy specjalnej przez autora opinii/ekspertyzy, proponowane jest uznanie eksperta prywatnego za podmiot tego przestępstwa. Nie jest także wykluczona sytuacja, w której opinię prywatną sporządziłby rzeczoznawca na potrzeby innego postępowania prowadzonego na podstawie ustawy, zaś opinia taka zostałaby wykorzystana przez podmiot nieinstytucjonalny na potrzeby postępowania karnego.

Czynność sprawcza czynu określonego w art. 233 § 4 i 4a k.k. polega na przedstawieniu opinii organowi procesowemu. W momencie przedłożenia jej przez biegłego, rzeczoznawcę organowi procesowemu, zaliczana jest ona w poczet materiału dowodowego. W przypadku ekspertyzy prywatnej to nie autor ekspertyzy decyduje o tym, czy jest ona przedstawiana w określonym postępowaniu prowadzonym na podstawie ustawy - w tym w postępowaniu karnym. Decyzję tę podejmuje ostatecznie podmiot, który zlecił jej sporządzenie - co ma znaczenie w zakresie znamion strony podmiotowej. Jednak zlecenie sporządzenia ekspertyzy prywatnej może wyraźnie wskazywać, iż będzie ona przedłożona $\mathrm{w}$ toku określonego postępowania, zaś ekspert przygotowując ją, będzie miał tego świadomość. Przesłanka w postaci przedłożenia opinii aktualizuje się w momencie, gdy osoba, która ją sporządziła, powzięła czynność zmierzającą do tego, aby opinia ta dotarła do organu procesowego. Wówczas aktualizuje się rodzajowy oraz indywidualny przedmiot ochrony. Odpowiedzialność karna grozi biegłemu lub rzeczoznawcy jedynie, gdy fałszywa opinia lub ekspertyza została sporządzona jako dowód w postępowaniu sądowym lub $\mathrm{w}$ innym postępowaniu prowadzonym na podstawie

${ }^{27}$ Biuletyn nr 354/VIII Komisja Nadzwyczajna do spraw zmian w kodyfikacjach /nr 9/, http://orka.sejm.gov.pl/Zapisy8.nsf/wgskrnr/NKK-9 [dostęp: 14.02.2021]. 
ustawy. Nie podlega zatem tej odpowiedzialności biegły lub rzeczoznawca, jeżeli opinia lub ekspertyza została sporządzona dla innych celów, np. jako ekspertyza prywatna, nie została przedłożona w postępowaniu jako dowód, wówczas nie godzi w dobro prawnie chronione, jakim jest prawidłowe funkcjonowanie wymiaru sprawiedliwości.

Minimalnym warunkiem spełnienia znamion strony podmiotowej $\mathrm{w}$ odniesieniu do przestępstwa $\mathrm{z}$ art. $233 \S 4$ k.k. jest przewidywanie przez sprawcę nieprawdziwości jego oświadczeń o posiadanych wiadomościach na temat faktów badanych $\mathrm{w}$ postępowaniu i zarazem godzenie się z tym stanem. W literaturze przedmiotu wskazuje się, że fałsz wymaga świadomości sprawcy odnośnie do tego, co jest prawdą, a co nie, chodzi tu o sytuację, gdy dana osoba zna prawdę i zmierza do tego, aby nie wyszła ona na jaw. W przypadku potwierdzenia nieprawdy sprawca musi mieć świadomość, że dane prezentowane w opinii są nieprawdziwe i potwierdzić ich prawdziwość, przy czym chodzi tu o subiektywne przekonanie biegłego ${ }^{28}$. Trudne do oceny byłoby uznanie, że ekspertyza została sporządzona fałszywie umyślnie bądź też nieumyślnie, z tego chociażby względu, że ekspert ją sporządzający bazuje na materiale dowodowym udostępnionym mu przez stronę. Również sugestie czynione przez zlecającego i powstający między zlecającym podmiotem a ekspertem stosunek obligacyjny sprawia, iż ekspert podświadomie utożsamia się ze swoim zleceniodawcą i chce wykonać zleconą mu pracę w taki sposób, który będzie zadowalał zlecającego. Przepis art. 233 § 4a k.k. z kolei penalizuje zachowania nieumyślne, a więc lekkomyślność lub niedbalstwo przy przedstawieniu opinii, ekspertyzy lub thumaczenia - lecz wtedy tylko, gdy doszło jednocześnie do narażenia interesu publicznego na istotną szkodę.

Należy się zastanowić nad tym, czy przesłanki strony podmiotowej wskazanych przestępstw (art. $233 \S 4$ i 4a k.k.) mogłyby dotyczyć także autora ekspertyzy prywatnej, który sporządzając ją w sposób pozwalający na uznanie jej za fałszywą, może mieć świadomość, że intencją podmiotu zlecającego mu jej opracowanie jest dowodowe wykorzystanie ekspertyzy w postępowaniu, o którym mowa w art. $233 \S 1$ k.k. Wina umyślna eksperta mogłaby przejawiać się $\mathrm{w}$ przewidywaniu przez niego nieprawdziwości zawartych w jego ekspertyzie i godzeniu się z tym stanem, tudzież celowym zawarciu nieprawdziwych treści $w$ ekspertyzie oraz przewidywaniu, że służyłaby ona podmiotowi zlecającemu jej sporządzenie do dowodowego wykorzystania w postępowaniu, o którym mowa w art. $233 \S 1$ k.k. Pamiętać należy jednak,

\footnotetext{
${ }^{28}$ M. BUDYN-KULIK, Kilka uwag o przestępstwie, s. 36.
} 
że czym innym jest sporządzenie opinii fałszywej, a czym innym opinii nierzetelnej, o tym wspomniano już we wstępie opracowania. Autor opinii prywatnej powinien opracować ją z należytą starannością, zgodnie z posiadaną wiedzą, doświadczeniem zawodowym, na podstawie aktualnego stanu wiedzy w danej dziedzinie, niezależnie od tego, czy efekt końcowy będzie zgodny z myślą zlecającego jej sporządzenie. Zachowania nieumyślne z kolei - jak wskazano wyżej - mogłyby polegać na niezachowaniu ostrożności przez sporządzającego opinię prywatną, który przewiduje, iż np. nieścisłości, niedopowiedzenia, braki w ekspertyzie, niezgodności z obowiązującymi przepisami źródłowymi, normami technicznymi, mogą doprowadzić do sporządzenia opinii fałszywej, ale sądzi, że tego uniknie lub w ogóle nie przewiduje takiej możliwości, chociaż powinien był i mógł to uczynić. W praktyce wykazanie przesłanki dotyczącej strony podmiotowej byłoby jednak niezwykle problematyczne, ponieważ wnioski przedstawiane w ekspertyzach prywatnych (jak i w opiniach biegłych) mogą nie być jednoznaczne, konkretne i pewne oraz prezentować różne warianty prawdopodobieństwa, a tym samym rodzić wątpliwości.

Reasumując powyższe rozważania, sporządzenie fałszywej ekspertyzy przez eksperta prywatnego nie wypełnia znamion czynu z art. $233 \S 4$ i 4a k.k. Przepisy te odnoszą się do osoby biegłego powołanego przez organ procesowy, nie zaś do osoby mającej wiedzę specjalną niepowołaną w tym charakterze. Biegły prywatny nie przedkłada organowi procesowemu sporządzonej przez siebie ekspertyzy, gdyż taką przedłożyć może podmiot, który zlecił jej wykonanie. $Z$ tego samego powodu odpowiedzialności na tej podstawie nie ponosiłby także rzeczoznawca sporządzający opinię/ekspertyzę na potrzeby innego postępowania prowadzonego zgodnie z ustawą, którą to opinię wykorzystał później podmiot nieinstytucjonalny na potrzeby postępowania karnego.

Należy wspomnieć o głęboko zakorzenionej zasadzie nullum crimen sine lege certa, wedle której przepisy karne powinny opisywać przestępstwo w sposób maksymalnie dokładny i precyzyjny, a także o zasadzie nullum crimen sine lege stricta, która wyraża zakaz analogii i wykładni rozszerzającej na niekorzyść sprawcy. Mając zatem na uwadze powyższe rozważania oraz wymienione zasady, należy stwierdzić, iż obecne brzmienie przepisu art. $233 \S 4$ i 4 a k.k. nie pozwala na pociągnięcie eksperta prywatnego do odpowiedzialności karnej za sporządzenie fałszywej ekspertyzy.

Warto zwrócić uwagę na instytucję pomocnictwa i zastanowić się, czy instytucja ta miałaby zastosowanie przy ewentualnej odpowiedzialności karnej eksperta prywatnego $\mathrm{w}$ ramach udzielenia pomocy $\mathrm{w}$ popełnieniu przestęp- 
stwa z art. 233 k.k. Dodać trzeba, że udzielający pomocy powinien wiedzieć, iż podejmując określone czynności, czyni to w odniesieniu do konkretnego, scharakteryzowanego $\mathrm{w}$ odpowiednim przepisie części szczególnej lub w przepisie pozakodeksowym czynu zabronionego, musi więc obejmować swoją świadomością zarówno prawną charakterystykę czynu zabronionego, którego popełnienie ma zamiar ułatwić, jak i znaczenie swojego zachowania (działania lub zaniechania), w tym w szczególności tego, że stanowi ono ułatwienie popełnienia czynu zabronionego przez inną osobę ${ }^{29}$. Ekspert prywatny, konsultując się z podmiotem zlecającym mu sporządzenie ekspertyzy, z reguły będzie miał świadomość tego, w jaki sposób zostanie ona wykorzystana. Trudno oprzeć się wrażeniu, że otrzymując ustalone ze zlecającym wynagrodzenie, sformułuje on korzystne dla niego wnioski ekspertyzy, przyjmując odpowiednie metody badawcze oparte na materiale dowodowym przekazanym mu przez zlecającego.

Rozpatrując kwestię pomocnictwa pod kątem przepisu z art. $233 \S 4$ k.k., wskazać należy, że pomoc miałaby być udzielana zlecającemu sporządzenie ekspertyzy prywatnej (a nie biegłemu, rzeczoznawcy, tłumaczowi), a - jak już zostało wyjaśnione - podmiotem tego przestępstwa jest biegły, rzeczoznawca, tłumacz, który wykonuje czynność i przedstawia opinię, ekspertyzę, tłumaczenie na podstawie zlecenia organu procesowego. Rozpatrując z kolei kwestię pomocnictwa pod kątem przepisu z art. $233 \S 1$ k.k., możliwy byłby stan faktyczny, w którym usługi eksperta prywatnego dla zlecającego mu przygotowanie ekspertyzy polegałyby także na ukierunkowywaniu zeznań świadków pod tezy zawarte w ekspertyzie prywatnej lub tezy przyjętej linii reprezentacji pokrzywdzonego/oskarżonego.

\section{WNIOSKI}

$\mathrm{Na}$ podstawie przeprowadzonej analizy, w tym analizy wyników badań ankietowych sformułować można kilka zasadniczych wniosków.

Ekspert prywatny sporządzający ekspertyzę prywatną nie może ponosić odpowiedzialności karnej za wykonanie fałszywej ekspertyzy na podstawie przepisu art. $233 \S 4$ i 4 a k.k. - w jego obecnym brzmieniu. Przepis ten odnosi się do osoby biegłego powołanego przez organ procesowy, nie zaś do osoby mającej wiedzę specjalną, która nie została powołana w tym charakterze. Ekspert prywatny nie jest zatem podmiotem tego przestępstwa. Nie

\footnotetext{
${ }^{29}$ Wyrok SA w Warszawie z 24.6.2015 r., II AKa 39/15, Legalis.
} 
przedkłada też organowi procesowemu swojej ekspertyzy, gdyż taką przedłożyć może podmiot, który zlecił jej sporządzenie. Ekspert prywatny nie ponosiłby także odpowiedzialności na podstawie art. $233 \S 4$ k.k. jako osoba udzielająca pomocy w popełnieniu tego przestępstwa, gdyż pomoc miałaby być udzielana zlecającemu sporządzenie ekspertyzy prywatnej (a nie biegłemu, rzeczoznawcy, tłumaczowi, tj. podmiotom tego przestępstwa). Nie byłaby jednak wykluczona odpowiedzialność z art. $233 \S 1$ k.k., gdzie usługi eksperta prywatnego dla zlecającego mu przygotowanie ekspertyzy prywatnej polegałyby na ukierunkowywaniu zeznań świadków pod tezy przedstawione w sporządzonej ekspertyzie prywatnej lub tezy przyjętej linii reprezentacji pokrzywdzonego/oskarżonego.

Autor opinii (ekspertyzy) prywatnej mógłby ponieść odpowiedzialność karną na podstawie art. $233 \S 1$ lub 4, 4a k.k., jednakże odpowiedzialność ta nie dotyczyłaby bezpośrednio sporządzenia przez niego fałszywej opinii (ekspertyzy) prywatnej. Odpowiedzialność na podstawie art. $233 \S 4$ lub 4a k.k. poniósłby wówczas, gdyby wykonał ekspertyzę na zlecenie podmiotu prywatnego, a następnie zostałby powołany w charakterze biegłego i powtórzyłby w wydanej na zlecenie organu procesowego opinii treść sporządzonej uprzednio fałszywej ekspertyzy. Odpowiedzialność karną na podstawie art. $233 \S 1$ k.k. poniósłby wówczas, gdyby został przesłuchany w charakterze świadka, pouczony o odpowiedzialności karnej zeznałby nieprawdę co do okoliczności związanych z opracowaniem opinii (ekspertyzy) prywatnej.

De lege ferenda należałoby się zastanowić nad uregulowaniem w przepisach kodeksu postępowania karnego statusu eksperta prywatnego i opinii (ekspertyzy) prywatnej, a także nad zmianą przepisu $233 \S 4$ k.k. poprzez ujęcie w grupie podmiotów eksperta prywatnego. Obecny katalog podmiotów wymienionych w tym przepisie uniemożliwia pociągnięcie do odpowiedzialności karnej eksperta prywatnego sporządzającego fałszywą ekspertyzę, przygotowaną na potrzeby postępowania karnego, a następnie wykorzystaną $\mathrm{w}$ toku postępowania karnego. Zmiana mogłaby być przeprowadzona $\mathrm{w}$ taki sposób, aby kwantyfikatorem odpowiedzialności danego podmiotu za popełniony czyn w postaci przedstawienia fałszywej opinii, ekspertyzy czy tłumaczenia było wyłącznie posiadanie przez osobę sporządzającą opinię kwalifikacji zawodowo-specjalistycznych w danej dziedzinie (w przypadku biegłego i rzeczoznawcy). Należałoby wówczas wyeliminować drugi kwantyfikator odpowiedzialności autora opinii, tj. procesowy sposób zlecenia sporządzenia opinii (powołanie przez organ procesowy), ewentualnie uzupełnić go przez np. zwrot: ,przedkłada bądź sporządza fałszywy dokument prywatny w formie 
ekspertyzy celem jej wykorzystania w procesie karnym". Niewątpliwie jednak takie rozszerzenie zakresu penalizacji z art. 233 k.k. wymagałoby znacznej rozwagi i pogłębionych analiz.

\section{PIŚMIENNICTWO}

\section{Źródla prawa}

Ustawa z dnia 23 kwietnia 1964 r. - Kodeks cywilny, Dz.U. z 1964 r., Nr 16, poz. 93 ze zm.

Ustawa z dnia 27 września 2013 r. o zmianie ustawy - Kodeks postępowania karnego oraz niektórych innych ustaw, Dz.U. z 2013 r., poz. 1247 ze zm.

Ustawa z dnia 6 czerwca 1997 r. - Kodeks postępowania karnego, Dz.U. z 1997 r., Nr 89, poz. $555 \mathrm{ze} \mathrm{zm}$.

Ustawa z dnia 19 kwietnia 1969 r. - Kodeks karny, Dz.U. z 1969 r., Nr 13, poz. 94 ze zm.

Ustawa z dnia 11 marca 2016 r. o zmianie ustawy - Kodeks postępowania karnego oraz niektórych innych ustaw, Dz.U. z 2016 r., poz. 437.

\section{Orzecznictwo}

Wyrok SN z 9.05.1988 r., II KR 96/88, OSNKW 1988/9-10, poz. 27.

Uchwała S.N. (7) z 22.02.2003 r., I KZP 39/02, OSNKW 1-2/2003, poz. 1, s. 3.

\section{Literatura}

BIEŃKOwSKA Beata: Opinia prywatna biegłego w świetle nowelizacji kodeksu postępowania karnego ustawa z dnia 27 września 2013 r., [w:] Wokót gwarancji wspótczesnego procesu karnego. Księga jubileuszowa Profesora Piotra Kruszyńskiego, red. M. Rogacka-Rzewnicka, H. Gajewska-Kraczkowska, B.T. Bieńkowska, Warszawa: Wolters Kluwer Polska 2015, s. 19-37.

BoJAŃCZYK Antoni: Czy znowelizowane przepisy procedury karnej pozwalaja obrońcy na korzystanie z opinii prywatnych?, „Palestra” 60 (2015), nr 3-4, s. 199-203.

Budyn-KuliK Magdalena: Kilka uwag o przestępstwie z art. 233 k.k. (składanie fatszywych zeznań) po nowelizacji z 11 marca 2016 r., „Annales Universitatis Maria Curie-Skłodowska”, sectio G. Ius, 63 (2016) 1, s. 23-40.

DudKa Katarzyna, PAluszKIEwicz Hanna: Postępowanie karne, Warszawa: Wolters Kluwer 2018.

EICHSTAEDT Krzysztof: Znaczenie opinii prywatnej w postępowaniu karnym, „Prokuratura i Prawo" 2015 , nr 4, s. 90-98.

Herzog Aleksander: Komentarz do art. 233 kk, [w:] Kodeks karny. Komentarz, red. R. Stefański, Warszawa: Wolters Kluwer 2021, wyd. 26, Legalis.

KMIECIK Radosław: Kontrowersyjne unormowania $w$ znowelizowanym kodeksie postępowania karnego, „Prokuratura i Prawo” 2015, nr 1-2, s. 10-24.

KuniCKA-MichalsKA Barbara: Komentarz do art. 233 kk, [w:] Kodeks karny. Komentarz, red. A. Wąsek, R. Zawłocki, t. II, Warszawa: C.H. Beck 2006, s. 1320-1348. 
NowAK Marcin: Wątpliwości związane z odpowiedzialnościa prawna biegłego sądowego w świetle znowelizowanego art. 233 \& 4 a kk, „Zeszyty Prawnicze” 17 (2017), nr 2, s. 78-79.

PAPRZYCKI Lech Krzysztof: Wykorzystanie opinii prywatnej w postępowaniu karnym, [w:] Prawo wobec problemów społecznych. Księga jubileuszowa profesor Eleonory Zielińskiej, red. B. Namysłowska-Gabrysiak, K. Syroka-Marczewska, A.Walczak-Żochowska, Warszawa: C.H. Beck 2016, s. 277-284.

PONIKOwSKi Radosław, ZAGRODNIK Jarosław: Komentarz do art. 393 kpk, [w:] Komentarz postępowania karnego, red. J. Skorupka, wyd. 28, Legalis.

SKORUPKA Jerzy: Tzw. opinia prywatna wedtug noweli Kodeksu postępowania karnego z 27.09. 2013 r., [w:] Rola biegłego w postępowaniach sądowych, red. Ł. Błaszczak, K. Markiewicz, Wrocław: Presscom 2016, s. 229-238.

WidŁA Tadeusz: Jeszcze raz o ekspertyzach pozasadowych, „Prokuratura i Prawo” 2015, nr 7-8, s. 36-43.

WIDŁA Tadeusz: Odpowiedzialność karna za wydanie fatszywej opinii, „Palestra” 63 (2018), nr 10, s. 13-18.

ZAGRODNIK Jarosław: Opinia prywatna w procesie karnym, [w:] Ogólnopolska Konferencja Naukowa 10-11 maj 2005 r. Dowody w procesie karnym, nowe rozwiazania i niewykorzystane możliwości, oprac. Koło Naukowe Sympatyków Prawa; opiekun nauk. K. Marszał, Katowice: Uniwersytet Śląski. Wydział Prawa i Administracji 2005, s. 67-68.

\section{Inne}

Biuletyn nr 354/VIII Komisja Nadzwyczajna do spraw zmian w kodyfikacjach, nr 9, http://orka. sejm.gov.pl/Zapisy8.nsf/wgskrnr/NKK-9 [dostęp: 14.02.2021].

\section{ODPOWIEDZIALNOŚĆ KARNA OSOBY SPORZĄDZAJĄCEJ FAŁSZYWĄ OPINIĘ PRYWATNĄ DLA CELÓW PROCESU KARNEGO}

\section{Streszczenie}

W artykule analizie poddano możliwość ponoszenia przez biegłego prywatnego odpowiedzialności karnej za sporządzenie fałszywej opinii prywatnej przedłożonej organowi procesowemu w toku postępowania karnego przez stronę tego postępowania. Przeprowadzona analiza przesłanek strony podmiotowej oraz przedmiotowej przestępstwa stypizowanego w art. $233 \S 4$ i $4 \mathrm{a}$ oraz w art. $271 \S 1$ Kodeksu karnego pozwoliła na udzielenie odpowiedzi na zasadnicze pytanie: czy tzw. biegły prywatny może ponosić odpowiedzialność karną za sporządzenie nieprawdziwej opinii prywatnej, ewentualnie czym ta odpowiedzialność jest uwarunkowana. Autor prezentuje także wyniki ogólnopolskich badań ankietowych przeprowadzonych wśród sędziów wydziałów karnych, w części dotyczącej ponoszenia odpowiedzialności karnej przez biegłych prywatnych.

Słowa kluczowe: postępowanie karne; fałszywa opinia prywatna; odpowiedzialność karna 